УДК 620.2:667.26

Г.І. ГОЛОДЮК

Луцький національний технічний університет

\title{
ФОРМУВАННЯ СПОЖИВНИХ ВЛАСТИВОСТЕЙ АЛКІДНОЇ ФАРБУВАЛЬНОЇ КОМПОЗИЦІї
}

Г.И.ГОЛОДЮК

Луиякий национальный технический университет

\author{
ФОРМИРОВАНИЕ ПОТРЕБИТЕЛЬСКИХ СВОЙСТВ АЛКІДНОЇ \\ ПОКРАСОЧНОЙ КОМПОЗИЦИИ
}

G.GOLODYUK

Lutsk national technical university

\section{FORMING OF CONSUMER PROPERTIES OF АЛКІДНОÏ OF A PAINT COMPOSITION}

\author{
https://doi.org/10.36910/6775-2310-5283-2019-12-08
}

Мета. Метою роботи є товарознавча оцінка нових фарбувальних композицій та лакофарбових покриттів для деревини листяних порід на основі алкідних смол.

Методика. Методологічну базу роботи склали фундаментальні $i$ прикладні дослідження і аналіз лакофарбових матеріалів, які представлені на ринку Украӥни, згідно діючих стандартів. В прочесі роботи використовувались матеріали статей та Інтернет - конференцій з даної теми дослідження.

Результати. Формування лакофарбових покриттів на деревині листяних порід на основі фарбувальної композииії відкриває широкий діапазон ї̈ застосування з різними за фізико-хімічними властивостями покривними лаками, щзо забезпечує ї̈ універсальність.

Попередніми дослідженнями встановлено, щь складна будова деревини обумовлює складнощі глибокого проникнення фарбувальних речовин у ї̈ середину. Під час поверхневого фарбування не можливо забезпечити глибоке проникнення фарбувального складу, максимальна глибина складає 0,07 - 0,2 мм, щуо пов'язане із несумірністю розміру частинок фарбника, клітин $i$ пор деревини.У результаті застосування рачіонально розробленої композиціі скорочується час сушіння покриття до 21 хв., щчо значно відрізняється від поренбейців на основі алкідних смол, час сушіння яких складає 180 хв. Ця обставина викликана малим вмістом лаку у фарбувальній композииії. Досягнута раџіональна глибина проникнення фарбувальної композиції у деревину 4,10 мкм, щзо викликана фізико-хімічними властивостями розчинника і малим вмістом лаку у фарбувальній композииії.

Наукова новизна. Полягає у тому, щзо визначено раціональні параметри рецептури фарбувального складу на основі алкідних смол для формування лакофарбового покриття на деревині листяних порід з поліпшеними експлуатачійними показниками; визначено оптимальні технологічні параметри нанесення фарбувальної композиції та алкідних лакофарбових покриттів на деревину листяних порід.

Практичне значення. Застосування розробленої алкідної фарбувальної композиції забезпечує отримання високоякісних покриттів на деревині листяних порід, виключаючи операцію проміжного шліфування, поєднуючи операчії трунтування $i$ фарбування при 
досить низькій собівартості. Застосування алкідної фарбувальної композииії знижує шорсткість поверхні забарвленої деревини за рахунок заповнення грунтлаком перерізаних порожнин клітин, судин, створюючи мікроплівку на поверхні деревної підкладки, закриваючи всі структурні нерівності. Дана композиція рівномірно розподіляється на деревній підкладчі, забезпечуючи рівномірність колірного забарвлення, зберігаючи при иьому текстуру деревини.

Ключові слова: фарбувальна композииія, лакофарбове покриття, поренбуйці, уайтспірит, шорсткість, деревина.

Поставка проблеми у загальному вигляді та її зв'язок із важливими науковими чи практичними завданнями. Формування лакофарбових покриттів на деревині листяних порід на основі фарбувальної композиції відкриває широкий діапазон іiі застосування з різними за фізико-хімічними властивостями покривними лаками, що забезпечує їі універсальність.

Проблемам дослідження властивостей фарбувальних композицій їх якості та безпечності присвячені наукові праці таких вчених: Хлоптунова Ю.В., Чижова М.А., Вєтошкін Ю.І., Дудла І.О., Лойко Д.П, Мережко Н.В., Черняк Л.В. та інші.

Цілі статті. Аналіз та вивчення змін споживчих властивостей фарбувальної композиції i лакофарбових покриттів на основі алкідних смол які використовуються для фарбування деревини листяних порід, а саме, берези.

Об'єкт дослідження. Об'єктом дослідження є фарбувальна композиція на основі алкідних смол і лакофарбові покриття.

Методи дослідження. Метод експертних оцінок та методи, які передбачені діючими стандартами.

Виклад основного матеріалу дослідження з повним обгрунтуванням отриманих наукових результатів. Деревина володіє своїми хімічними та фізичними властивостями і має складну анатомічну будову, іii поверхня перерізана порожнинами клітин, які утворюють канавки 3 поглибленнями, направленими всередину канавок. Ця обставина переважає за будь-якого розташування площини зрізу i зумовлена капілярно-пористою будовою деревини. Формування лакофарбового покриття на деревині фарбувальною композицією на основі алкідної смоли - складний фізико-хімічний процес. Це пов'язано 3 тим, що композиція містить складники, кожний 3 яких відрізняється за фізичним і хімічними властивостями.

За даними проведених пробних експериментів i теоретичного дослідження процесу взаємодії алкідної фарбувальної композиції з деревною підкладкою встановлено, що дана композиція дозволяє одержувати високоякісні покриття. При цьому слід зазначити позитивні моменти, а саме 


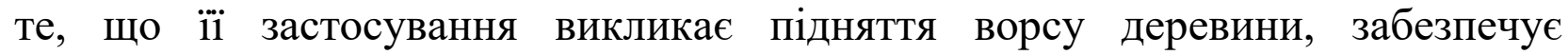
рівномірність кольору і дозволяє поєднати операції грунтування і фарбування деревини.

Поглинання поверхневими шарами деревини лакофарбових матеріалів, що наносяться на неї, до складу яких входять розчинники, супроводжується їх набуханням і може викликати появу нерівностей у вигляді підняття ворсу. Набухання поверхні деревини неоднакове в різних рідинах і залежить від відносної діелектричної проникності рідини. Полярність деревини пов'язана 3 iі діелектричною проникністю. Максимальне набухання деревини відбувається у воді; із зменшенням ступеня діелектричної проникності $\varepsilon$ ступінь поглинання рідин зменшується. Деревина практично не набухає у рідинах $3 \varepsilon \leq 5$-ароматичних (уайт-спірит) i особливо аліфатичних вуглеводнях (бензол, толуол, ксилол), при цьому спостерігається лише їх часткове вбирання. Таким чином склад розчинників у лакофарбових матеріалах, що наносяться безпосередньо на деревину, впливає на стабільність їі поверхні і формування якісного покриття [2].

Уайт-спірит, що входить до складу фарбувальної композиції, $\epsilon$ неполярним розчинником 3 низьким ступенем діелектричної проникності $\varepsilon$, що свідчить про те, що даний розчинник не вступає в реакцію 3 деревиною тому набухання і підняття ворсу деревини не спостерігається.

Формування покриттів на основі плівкоутворювачів відбувається, зазвичай, за рахунок видалення розчинників, випаровування і хімічних перетворень. Унаслідок випаровування розчинника з нерухомої затверділої плівки товщина лакофарбового покриття поволі зменшується до остаточної товщини, при цьому триває процес його втягування у поглиблення підкладки.

Лакофарбовий матеріал, нанесений на поверхню деревних виробів, вже не може вільно змінювати свій об’єм, внаслідок чого у покриттях виникають внутрішні напруги, тому виникає припущення про можливість появи ворсу на поверхні підкладки з деревини.

Під час висихання покриття в ньому утворюються усадкові напруги, що викликають зсідання плівки, яка, зменшуючись у об’ємі, просідає у поглиблення деревини і тягне за собою ворсинки деревини, здиблюючи їх. Як наслідок, підвищується шорсткість поверхні деревини.

Це доводить необхідність досліджень величини усадкових напруг, що виникають у покритті, яке висихає. 
Клейкість поєднує у собі чинники, що характеризують термодинамічну роботу: адгезія, когезія, поверхневий натяг, в'язкість [4]. Отже, важливо дослідити величину клейкості досліджуваної фарбувальної композиції.

За критерій оцінки клейкості приймається величина питомої сили відриву. Результати вимірювання клейкості представлені на графіку (рис. 1). У результаті випробувань на клейкість приймаємо за максимальну масу, яку здатна витримати фарбувальна композиція $m=34,9 \cdot 10^{-3} \kappa 2$. Перерахуємо масу $m$ як питому силу відриву $P$, що діє на одиницю площі, $\mathrm{H} / \mathrm{M}^{2}$.

$$
P=\frac{m \cdot g}{S}
$$

де $S$ - площа контакту $\left(9,61 \cdot 10^{-4} \mathrm{M}^{2}\right)$.

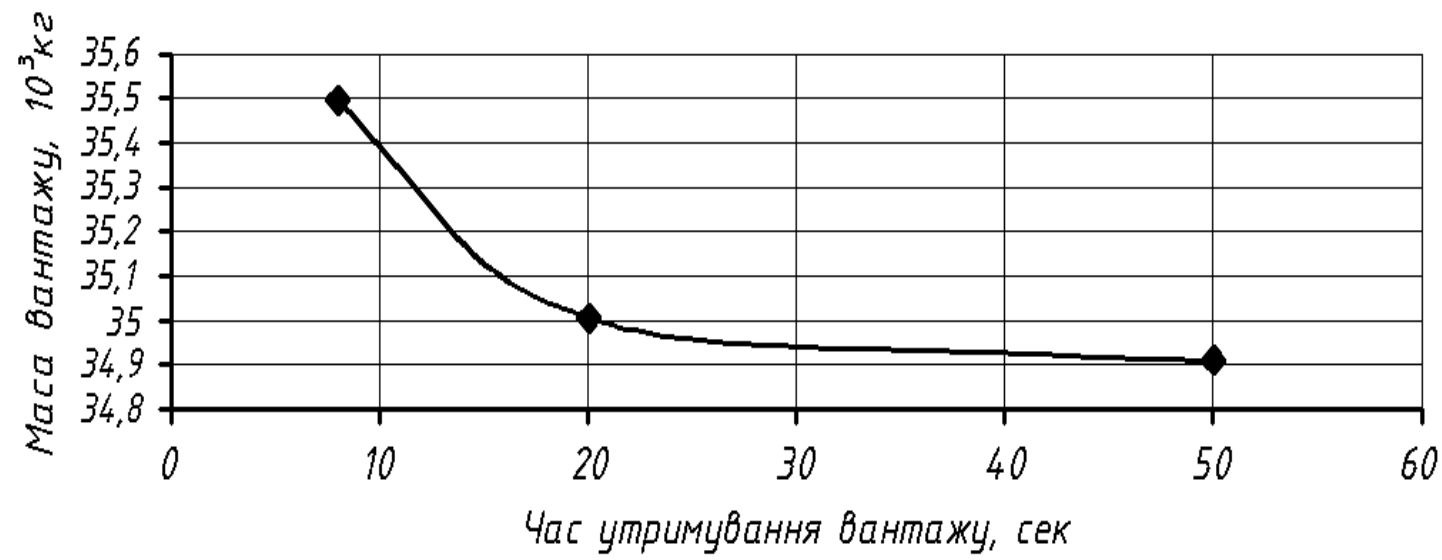

Рис. 1. Графік зміни клейкості фарбувальної композиції на основі алкідних смол

Величина $P=363,1 \mathrm{H} / \mathrm{s}^{2}$ - клейкість досліджуваної композиції або тиск, який він здатний витримати.

Для порівняння $q$ з $P$, перемножимо $P$ на ширину сталевої пластинки, на яку наносили фарбувальну композицію під час визначення $q$ :

$$
P=P b=363,1 \cdot 6,9 \cdot 10^{-3}=2,5, H / M .
$$

Порівняння одержаних результатів підтверджує теорію зниження шорсткості поверхні деревини під час фарбування досліджуваною композицією, оскільки $P \geq q$. Переведемо напруги, що виникають у фарбувальній композиції, на деревину. Представимо умовно ворсинку деревини, як балку із затисненим кінцем, а напруги, що виникають у досліджуваній композиції, як розподілене навантаження, що діє на балку (рис. 2).

$$
\begin{gathered}
\left\{\begin{array}{l}
\sum F_{y}=0 \\
\sum F_{x}=0
\end{array}\right. \\
Q-P^{\prime} \cdot z+q \cdot z=0,
\end{gathered}
$$




$$
\begin{aligned}
& Q=P^{\cdot} \cdot z-q \cdot z, \\
& \sum M=0, \\
& -P^{\prime} \cdot z \cdot \frac{z}{2}+q \cdot z \cdot \frac{z}{2}-M=0 \\
& M=-P \cdot \frac{z^{2}}{2}+q \cdot \frac{z^{2}}{2},
\end{aligned}
$$
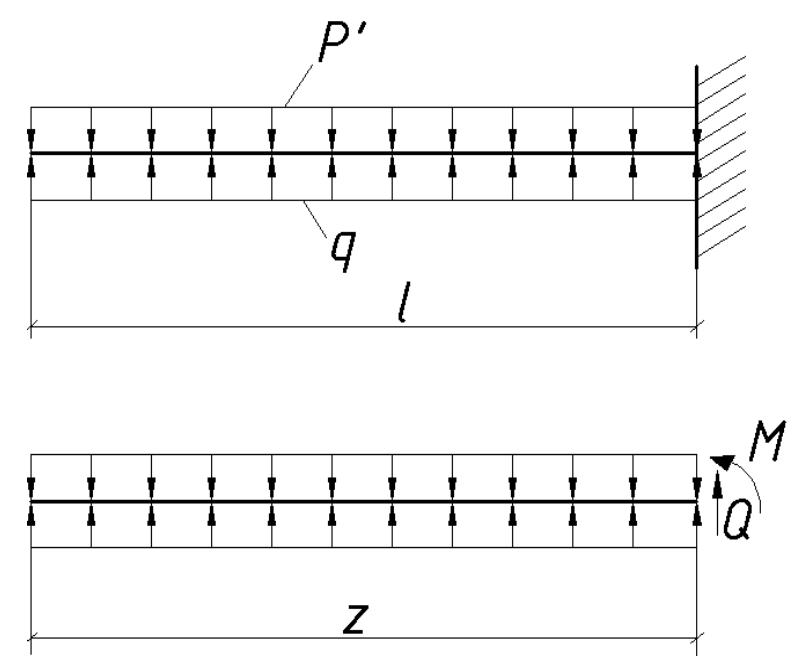

Рис. 2. Схематичне зображення ворсинки деревини, як балки із затисненим кінцем і навантаження, що діють на неї

Знаючи розміри деревних волокон, умовно задамо довжину балки. Прийнявши умовну довжину $l$ балки $3 \cdot 10^{-3} \mathrm{M}$, визначимо величину поперечних сил $Q$, $(H)$ і моментів згинання $M$, (H·м), що виникають у балці, $\mathrm{i}$ побудуємо епюри (рис. 3).
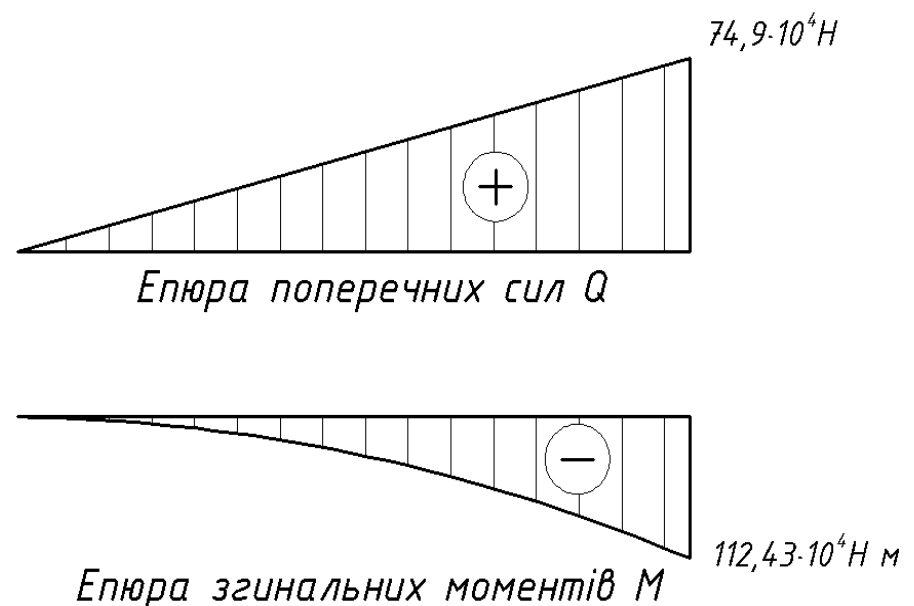

Рис.3. Епюри поперечних сил $Q$ і згинаючих моментів $M$

Результати обчислення епюр поперечних сил i моментів згинання при $P^{\prime}=2,5 \mathrm{H} / \mathrm{м}$ і $q=1,53 \cdot 10^{-3} \mathrm{H} / \mathrm{M}$, зведені у таблиці 1 . 
Таблиця 1

Величини поперечних сил і моментів згинання

\begin{tabular}{|c|c|c|}
\hline$Z, \mathrm{M}$ & $Q, \mathrm{H}$ & $M, \mathrm{H} \cdot \mathrm{M}$ \\
\hline 0 & 0 & 0 \\
\hline $0,5 \cdot 10^{-3}$ & $12,5 \cdot 10^{-4}$ & $-3,12 \cdot 10^{-7}$ \\
\hline $1.0 \cdot 10^{-3}$ & $24,9 \cdot 10^{-4}$ & $-12,49 \cdot 10^{-7}$ \\
\hline $1.5 \cdot 10^{-3}$ & $37,5 \cdot 10^{-4}$ & $-28,11 \cdot 10^{-7}$ \\
\hline $2,0 \cdot 10^{-3}$ & $49,9 \cdot 10^{-4}$ & $-49.97 \cdot 10^{-7}$ \\
\hline $2,5 \cdot 10^{-3}$ & $62.5 \cdot 10^{-4}$ & $-78.07 \cdot 10^{-7}$ \\
\hline $3.0 \cdot 10^{-3}$ & $74.9 \cdot 10^{-4}$ & $-112,43 \cdot 10^{-7}$ \\
\hline
\end{tabular}

Одним із показників, що характеризують якість одержуваного покриття на деревині після нанесення фарбувальної композиції, $\epsilon$ шорсткість.

Нами були проведені експериментальні дослідження зміни шорсткості поверхні (після нанесення композиції) залежно від різного вмісту грунтлаку, пігментної пасти при змінних значеннях витрат матеріалу і температури сушіння композиції.

За результатами експериментальних даних була побудована графічна залежність зміни шорсткості від змінних чинників (рис. 4-7).

Графічна залежність зміни шорсткості поверхні від вмісту лаку у досліджуваній фарбувальній композиції наведено на рис.4.

Як видно з графіка (рис. 4), шорсткість при вмісті лаку 20 мас. \%, складає 10,99 мкм.

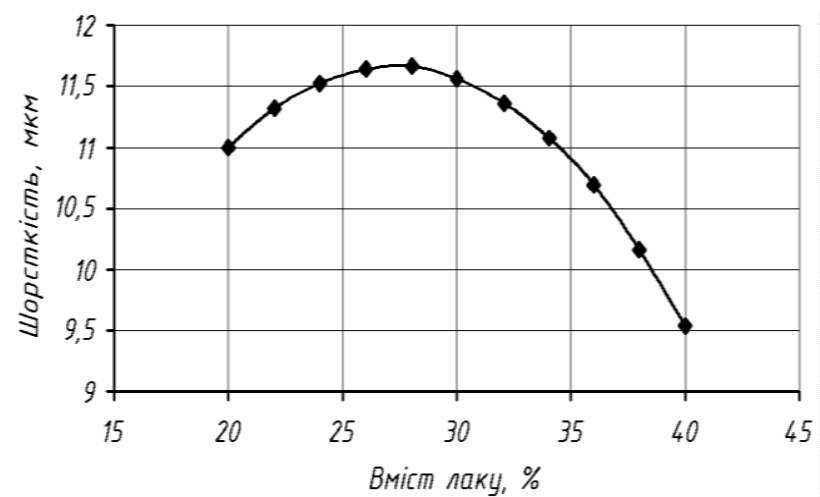

Рис. 4. Залежність зміни шорсткості поверхні від вмісту лаку у досліджуваній фарбувальній композиції (початкова шорсткість деревинної підкладки перед нанесенням фарбувальної композиції склала $\geq 16$ мКм)

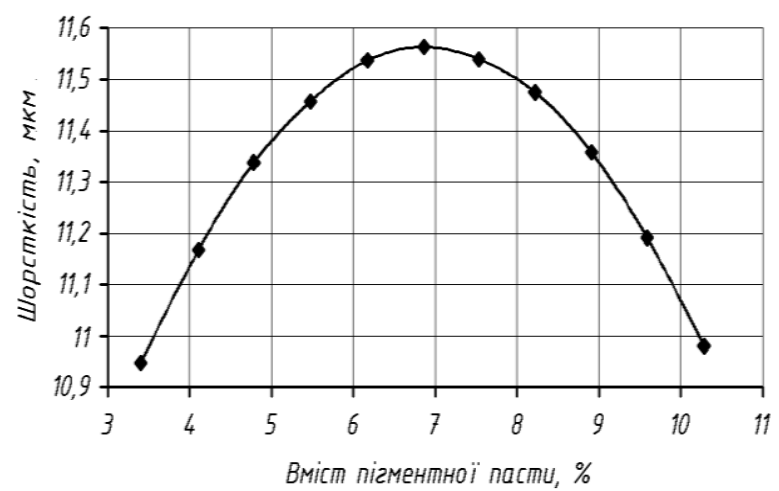

Рис. 5. Залежність зміни шорсткості поверхні від вмісту пігментної пасти, що вводиться у досліджувану фарбувальну композицію

Таке зниження шорсткості деревної підкладки з 13 мкм до 10,99 мкм пояснюється формуванням на поверхні підкладки тонкої плівки лаку. Збільшення вмісту лаку з 20 мас. \% до 28 мас. \% приводить до збільшення 
шорсткості 3 10,99 мкм до 11,65 мкм. Значне збільшення вмісту лаку приводить до збільшення часу сушіння і часу перебування складу у рідкому стані. Фарбувальна композиція за рахунок адсорбції проникає у порожнини перерізаних кліток, судин деревини, і на поверхні деревини залишається плівка лаку меншої товщини.

Збільшення вмісту лаку 328 мас. \% до 40 мас. \% у фарбувальній композиції приводить до зменшення показника шорсткості до 9,55 мкм. Велика кількість лаку у фарбувальній композиції приводить до заповнення перерізаних порожнин кліток, судин, утворюючи товстішу плівку на поверхні деревної підкладки, закриваючи всі структурні нерівності.

Графічна залежність зміни шорсткості поверхні від вмісту пігментної пасти, що вводиться у досліджувану фарбувальну композицію рис.5.

Графічна залежність шорсткості від витрати досліджуваної фарбувальної композиції рис.6.

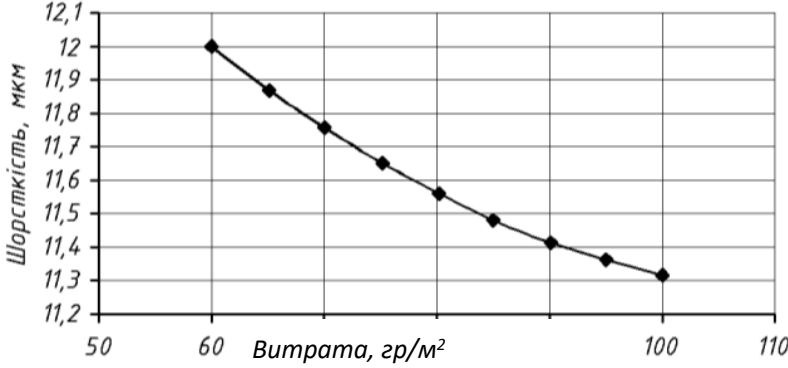

Рис. 6. Зміна шорсткості від витрати досліджуваної фарбувальної композиції

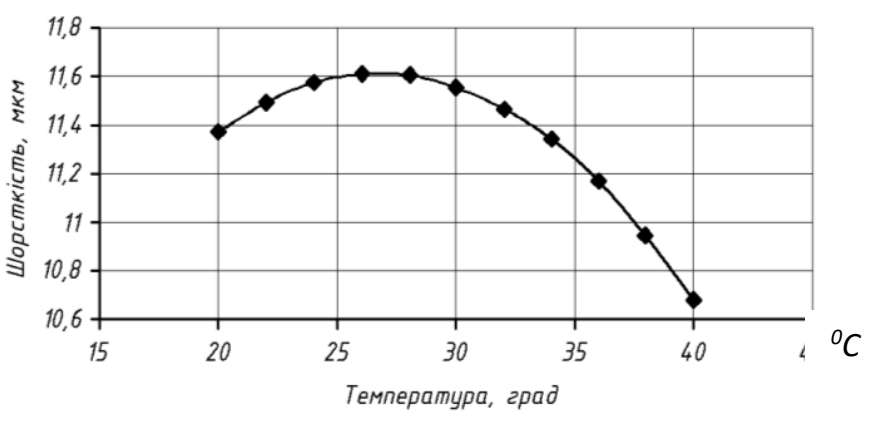

Рис. 7. Залежність зміни шорсткості поверхні від температури сушіння досліджуваної композиції фарбувальної композиції

3 даних графіка (рис. 7) видно, що при вмісті пігментної пасти 3,42 \%, шорсткість складає 10,94 мкм і при вмісті пігментної пасти 6,84 \% відповідно 11,56 мкм. Таку зміну шорсткості можна пояснити тим, що пігментна паста при малому вмісті $(3,42 \%)$ у складі заповнює лише западини у шорсткій поверхні. При збільшенні вмісту пігментної пасти до 6,84\% шорсткість збільшується за рахунок того, що пігментна паста заповнює не тільки западини поверхні, але й закриває виступи. При подальшому збільшенні вмісту пігментної пасти від 6,84 до 10,26\% шорсткість зменшується до 10,97 мкм. Це пов'язано з тим, що пігментна паста товстим шаром закриває западини і верхівки шорсткої поверхні. На графіку рис. 8 спостерігається зменшення шорсткості від 11,99 мкм до 11,31 мкм із збільшенням витрати фарбувальної композиції від 60 до 100 г/м². Таке зниження шорсткості 
пояснюється тим, що велика кількість нанесеної на деревинну підкладку композиції закриває шорсткість поверхні.

Графічна залежність зміни шорсткості поверхні від температури сушіння фарбувальної композиції наведена на рис. 9.

На графіку рис. 9 спостерігається збільшення шорсткості 3 11,37 до 11,61 мкм за збільшення температури від 20 до $26^{\circ} \mathrm{C}$. Таке зростання показника шорсткості можна пояснити тим, що швидкість сушіння складу є невисокою і склад просочується у середину підкладки, трохи приховуючи шорсткість. За подальшого збільшення температури до $40{ }^{\circ} \mathrm{C}$ шорсткість поверхні зменшується до 10,67 мкм, що пояснюється тим, що швидкість сушіння зростає і склад не встигає вбиратися у підкладку, висихаючи на поверхні, приховуючи шорсткість деревної підкладки.

Шорсткість деревної підкладки знижується після нанесення фарбувальної композиції, що видно з наведених вище графіків. Початкова шорсткість деревної підкладки $\geq 16$ мкм, після нанесення складу показник шорсткості знижується на 20 - 25 \%. За результатами експериментальних даних була побудована графічна залежність зміни глибини проникнення фарбувальної композиції в деревину від змінних чинників (рис. 8 - 11).

Для розгляду окремого впливу кожного 3 одиничних чинників на вихідний параметр, необхідно виключати почергово з рівняння регресії решту чинників, залишаючи той, що розглядається.

Графічна залежність зміни глибини проникнення фарбувальної композиції у деревинну підкладку від вмісту лаку показана на рис. 8.

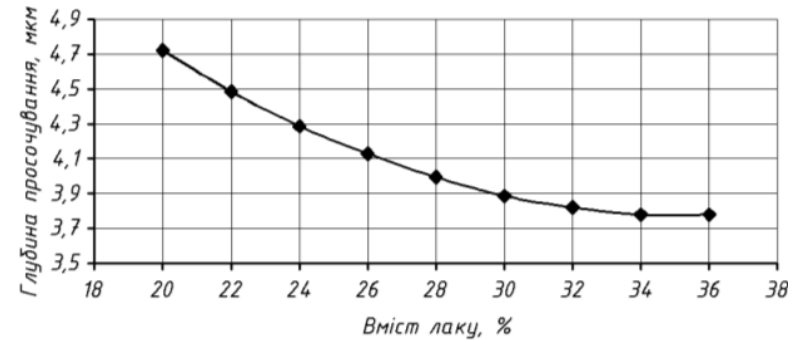

Рис. 8. Залежність зміни глибини проникнення фарбувальної композиції у деревинну підкладку від вмісту лаку

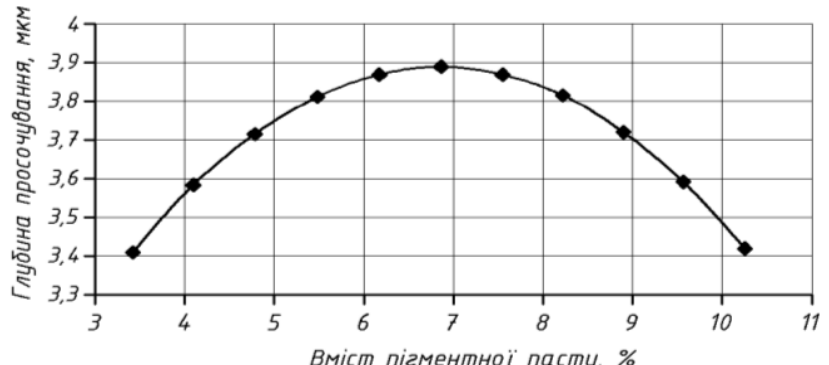

Рис. 9. Залежність зміни глибини проникнення фарбувальної композиції у деревинну підкладку від вмісту пігментної пасти

Як видно з графіка (рис.8), глибина просочення зменшується з 4,71 до 3,77 мкм при збільшенні вмісту лаку з 20 до 36 \%. Отже, збільшення вмісту лаку перешкоджає його проникненню у деревну підкладку внаслідок зростання в'язкості композиції. 
Графічна залежність зміни глибини проникнення фарбувальної композиції у деревинну підкладку від вмісту пігментної пасти подана на рис. 9. На графіку (рис. 9) спостерігається збільшення глибини проникнення фарбувальної композиції з 3,41 до 3,89 мкм при збільшенні вмісту пігментної пасти 3 3,42 до 6,84\%. Склад 3 малим вмістом пігментної пасти менш наповнений, не встигає просочити деревну підкладку, випаровуючись 3 поверхні. Відбувається процес активного випаровування розчинника. Збільшення вмісту пігментної пасти у складі до 6,84 \%, збільшує глибину проникнення фарбувального складу до 3,9 мкм, пігментна паста створює бар'єр, який перешкоджає швидкому випаровуванню розчинника 3 поверхні деревної підкладки. Подальше збільшення вмісту пігментної пасти до 10,26 \%, приводить до зменшення глибини просочення до 3,42 мкм.

Графічна залежність зміни глибини проникнення фарбувального складу у деревну підкладку від витрати рис. 10.

На графіку (рис. 10) спостерігається зменшення глибини проникнення фарбувальної композиції з 4,6 до 3,87 мкм із збільшенням витрати композиції від 60 до 75 г/ $\mathrm{M}^{2}$.

Збільшення витрати фарбувальної композиції з 75 до 100 г/м² приводить до поступового збільшення глибини просочення до 5,26 мкм. Фарбувальна композиція створює на деревній підкладці шар, що забезпечує тривалий час перебування складу у рідкому стані, тривалий час сушіння, що дозволяє забезпечити значну глибину просочення.

Графічне зображення залежності зміни глибини проникнення досліджуваної фарбувальної композиції у деревну підкладку від температури сушіння рис. 11.

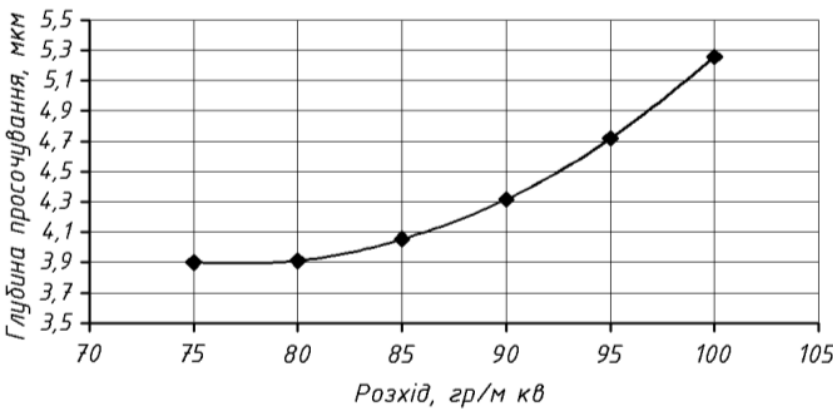

Рис. 10. Залежність зміни глибини проникнення фарбувального складу у деревну підкладку від витрати

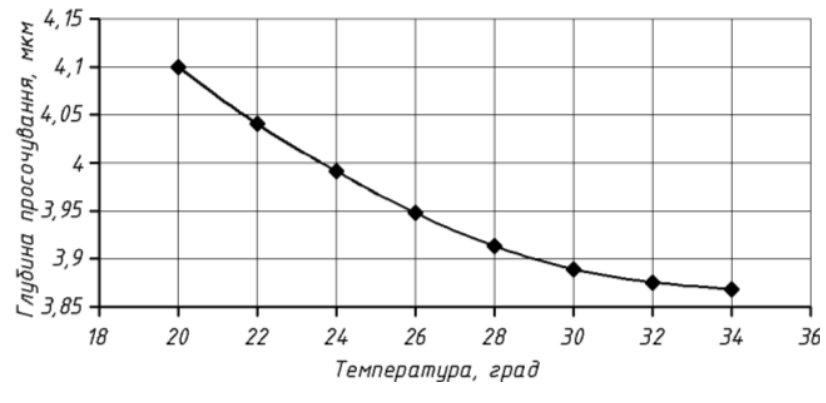

Рис. 11. Залежність зміни глибини проникнення досліджуваної фарбувальної композиції у деревну підкладку від температури сушіння 
На графіку (рис. 11) спостерігається зменшення глибини проникнення фарбувальної композиції з 4,09 до 3,86 мкм із збільшенням температури сушіння від 20 до $34^{\circ} \mathrm{C}$. За збільшення температури відбувається розширення повітря, що знаходиться у порожнинах кліток і каналах деревної підкладки. Повітря, виходячи на поверхню, перешкоджає глибокому проникненню фарбувальної композиції у деревну підкладку. За збільшення температури 3 $34{ }^{\circ} \mathrm{C}$ до $40{ }^{\circ} \mathrm{C}$ спостерігається збільшення глибини просочення до 3,9 мкм. Збільшення глибини проникнення викликане нагріванням і розрідженням фарбувальної композиції, оскільки розріджений склад легше адсорбується целюлозними волокнами деревної підкладки. Для розгляду окремого впливу кожного з одиничних чинників на вихідний параметр необхідно виключити 3 рівняння регресії решту чинників, за чергою залишаючи той, що розглядається. Графічне зображення залежності зміни тривалості затвердіння фарбувальної композиції, від вмісту лаку, що вводиться до складу рис. 12.

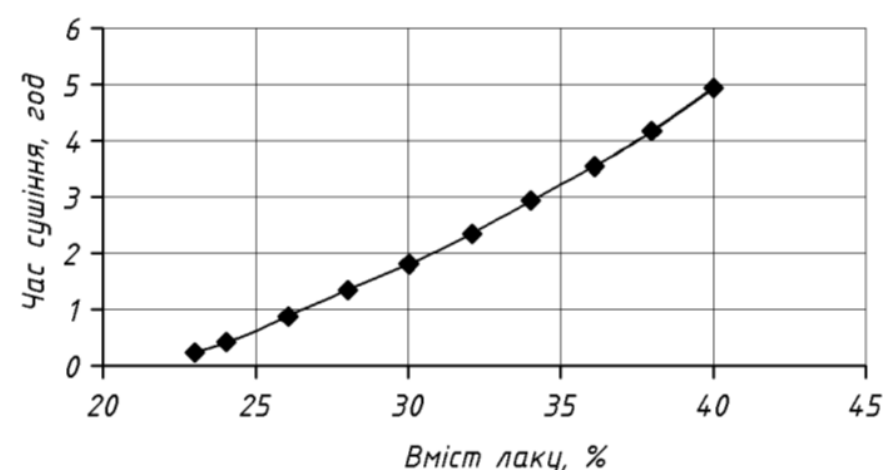

Рис. 12. Залежність зміни тривалості затвердіння фарбувальної композиції, від вмісту лаку, що вводиться до складу

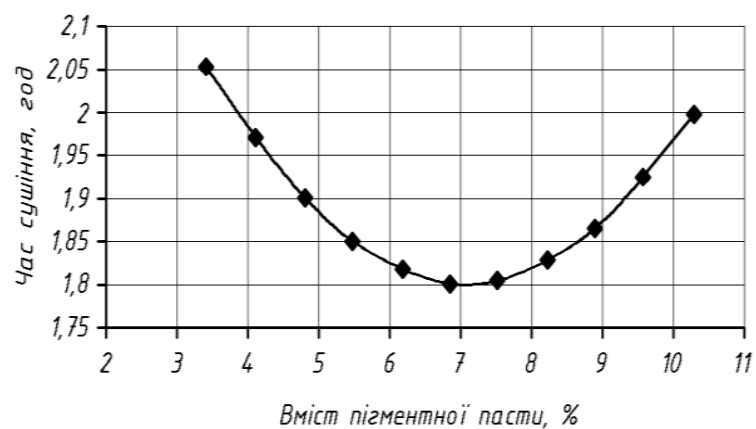

Рис. 13. Залежність зміни часу твердіння фарбувальної композиції від вмісту пігментної пасти, що вводиться

На графіку (рис.12) спостерігається збільшення часу сушіння фарбувальної композиції з 0,22 до 4,9 год. при збільшенні вмісту лаку з 23 до 40 мас.\%, який вводиться у склад композиції. Товщина покриття, утвореного фарбувальною композицією на деревній підкладці, залежить від вмісту лаку, що вводиться. Процес затвердіння покриттів на основі пентафталевих лаків відбувається у дві стадії, спочатку випаровується розчинник, а потім настає хімічне затвердіння. На затвердіння товстошарових покриттів витрачається більше часу через утворення поверхневої плівки гелю, що заважає просуванню розчинників з нижніх шарів до поверхні. Графічне зображення залежності зміни часу твердіння фарбувальної композиції від вмісту пігментної пасти, що вводиться рис. 13. 
На графіку (рис. 13) спостерігається скорочення часу затвердіння покриття з 2,05 до 1,8 години при збільшенні вмісту введеної у фарбувальну композицію пігментної пасти 3 3,42\% до 6,84 мас.\%. Значне збільшення вмісту пігментної пасти сприяє розбиванню поверхневого шару гелю, що утворюється при затвердінні пентафталевого лаку, і збільшує час твердіння покриття. Мікроскопічні пігменти розбивають поверхневий шар гелю i сприяють проникненню повітря у лакофарбове покриття, a також випаровуванню розчинника, скорочуючи час сушіння покриття. Подальше збільшення вмісту пігментної пасти до 10,26 мас.\% приводить до збільшення часу сушіння композиції до 1,99 годин. Значний вміст пігментів створює бар'єрний шар на поверхні, який перешкоджає взаємодії фарбувальної композиції з оксигеном повітря і гальмує процес випаровування розчинника, що викликає збільшення часу затвердіння пентафталевого лаку, який входить до складу фарбувальної композиції. Отже оптимальний вміст пігментної пасти у складі фарбувальної композиції становить 6,84 мас.\%.

Графічне зображення залежність зміни тривалості затвердіння. фарбувальної композиції від витрати рис.14. На графіку (рис. 14) спостерігається збільшення тривалості затвердіння фарбувальної композиції 3 1,74 до 3,03 години при збільшенні витрати 375 до 100 г/ $\mathrm{M}^{2}$. Тому при збільшенні витрати композиційного матеріалу утворюються покриття більшої товщини, а процес затвердіння товстошарових покриттів $є$ тривалішим через утворення поверхневої плівки гелю, що заважає просуванню розчинників 3 нижніх шарів до поверхні.

Залежність впливу температури сушіння фарбувальної композиції на тривалість сушіння, представлене графічно на рис. 15.

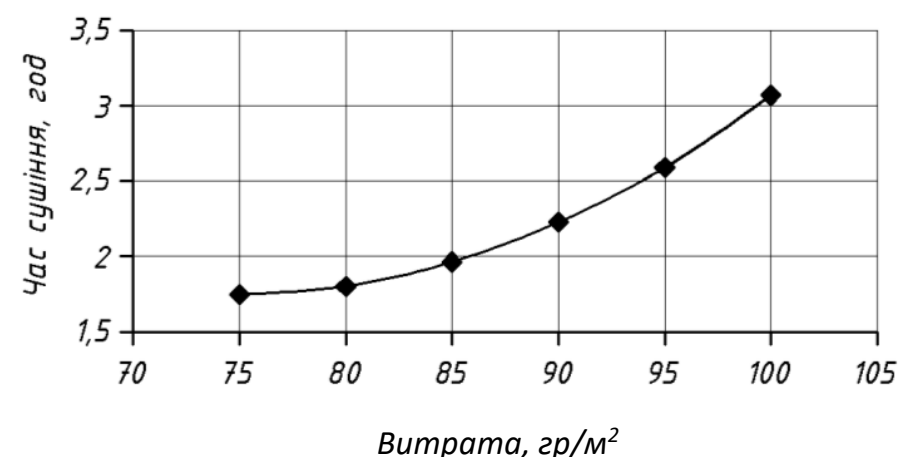

Рис. 14. Залежність зміни тривалості затвердіння фарбувальної композиції від витрати

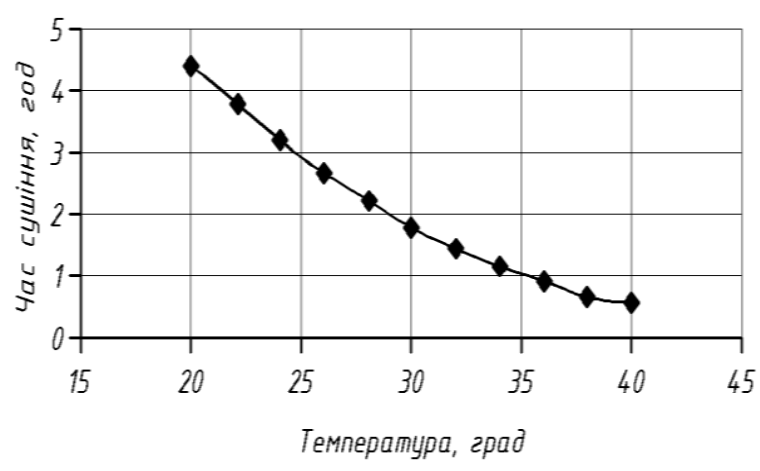

Рис. 15. Залежність зміни тривалості затвердіння досліджуваної фарбувальної композиції від температури сушіння 
На графіку (рис. 15) спостерігається скорочення часу затвердіння фарбувальної композиції з 4,4 до 0,56 години за підвищення температури сушіння 320 до $40{ }^{\circ} \mathrm{C}$. Підвищення температури висихання інтенсифікує процес затвердіння фарбувальної композиції, прискорюючи процес випаровування розчинників з фарбувальної композиції. Процес затвердіння проходить у дві стадії: спочатку випаровується розчинник, а потім відбувається хімічне затвердіння. Швидкість затвердіння на першій стадії залежить від швидкості зміни середнього вмісту розчинника у середині плівки лакофарбового покриття і середньої температури цієї плівки (внутрішнього масо- i теплоперенесення), а також від взаємодії поверхні плівки 3 навколишнім середовищем (зовнішнього масо- і теплообміну). Збільшення температури прискорює процес випаровування розчинників, що пов'язане із збільшенням швидкості руху молекул розчинів, ослабленням їх міжмолекулярних зв'язків i, як наслідок, швидшим видаленням летких компонентів з середини лакофарбових матеріалів.

Висновки та перспективи поданих досліджень. Застосування алкідної фарбувальної композиції знижує шорсткість поверхні забарвленої деревини за рахунок заповнення грунтлаком перерізаних порожнин клітин, судин, створюючи мікроплівку на поверхні деревної підкладки, закриваючи всі структурні нерівності. Дана композиція рівномірно розподіляється на деревній підкладці, забезпечуючи рівномірність колірного забарвлення, зберігаючи при цьому текстуру деревини.

\section{Список використаних джерел}

1. Дудла I.О. Дослідження сучасних фарбувальних речовин для деревини / Дудла I.О. Голодюк Г.І. // Товарознавчий вісник: Збірник наукових праць. Луцький національний технічний університет. Редкол.: відпр. ред. д.т.н., професор Байдакова Л.І. Луцьк, 2009: ЛНТУ, 2009. - С. 93-102.

2. Дудла I.О. Проблема модифікації алкідних лакофарбових покриттів / I.О. Дудла, Г.І. Голодюк // Товарознавство та торгівельне підприємництво: фахова професіоналізація, дослідження, інновації: міжнар. наук.-практ. конф., 15-16 квітня 2009 р.- Київ : Видавничий центр Київський національний торговельно-економічний університет, 2009. - С.189-191.

3. Голодюк Г.І. Дослідження атмосферостійкості фарбувальної композиції i лакофарбових покриттів на основі алкідних смол / Г.І. Голодюк // Товарознавчий вісник: Збірник наукових праць. - Луцьк, 2011. - Випуск 3. - С. 62-67.

4. Рішення на видачу деклараційного патенту на корисну модель “Алкідна лакофарбова композиція” № 10806/3У/11 від 26.05.2011p., затверджено Державним департаментом інтелектуальної власності Голоднюк Г.І., Дудла I.О.

Цель. Целью работы является товароведная оченка новых красящих композищий и 
лакокрасочных покрытий для древесины лиственных пород на основе алкидных смол.

Методика. Методологическую базу работы составили фундаментальные и прикладные исследования и анализ лакокрасочных материалов, представленных на рынке Украины, согласно с действующиим стандартам. В прочессе работь использовались материалы статей и Интернет - конференций по данной теме исследования.

Результаты. Формирования лакокрасочных покрытий на древесине лиственных пород на основе красящей композиции открывает широкий диапазон ее применения с различными по физико-химическим свойствам покровныли лаками, обеспечивает ее универсальность. Предылущими исследованиями установлено, что сложное строение древесины обусловливает сложности глубокого проникновения красящих веществ в ее середину. Во время поверхностного окрашивания невозможно обеспечить глубокое проникновение красящего состава, максимальная глубина составляет 0,07 - 0,2 мм, что связано с несоизмеримостью размера частии красителя, клеток и пор древесины.

В результате применения рациионально разработанной композиции сокращается время сушки покрытия до 21 мин., что значительно отличается от поренбейцов на основе алкидных смол, время сушки которых составляет 180 мин. Это обстоятельство вызвано мальм содержанием лака в покрасочной композиции. Достигнута раџиональная глубина проникновения красящей композиции в древесину 4,10 мкм, вызванной физико-химическими свойствами растворителя и мальмм содержанием лака в покрасочной композиции.

Научная новизна. Заключается в том, что определены рациональные параметры рецептуры красящего состава на основе алкидных смол для формирования лакокрасочного покрытия на древесине лиственных пород с улучшенными эксплуатационными показателями; определень оптимальные технологические параметры нанесения красящего композиции и алкидных лакокрасочных покрытий на древесину лиственных пород.

Практическое значение. Применение разработанной алкидной красящей композиции обеспечивает получение высококачественных покрытий на древесине лиственных пород, исключая операчию промежуточного шлифования, сочетая операчии грунтования $и$ окраски при достаточно низкой себестоимости. Применение алкидной красящей композиции снижает шероховатость поверхности окрашенной древесины за счет заполнения грунтлаком перерезанных полостей клеток, сосудов, создавая микропленку на поверхности древесной подложки, закрывая все структурные неровности. Данная композиция равномерно распределяется на древесной подложке, обеспечивая равномерность ияветовой окраски, сохраняя при этом текстуру древесины.

Ключевые слова: окрасочная композииия, лакокрасочное покрытие, поренбуйии, уайт-спирит, шероховатость, древесина.

Purpose. The purpose of the article is the commodity evaluation of new coloring compositions and paint coatings for wood based on alkyd resins.

Methodology. The methods of fundamental and applied research were used. Analysis of paintwork materials on the Ukrainian market was carried out in accordance with the current standards. Materials of articles and Internet conferences were also used during the research.

Results. The formation of paint coatings on hardwood on the basis of the coloring composition provides a wide range of its application with coating varnishes of different physical and chemical properties, ensures its versatility. Previous studies have established that the complex structure of wood causes the complexity of the deep penetration of dyes inside the wood. During the surface staining it is impossible to ensure deep penetration of the coloring composition, the maximum depth is 0.07-0.2 mm, which occurs due to the incommensurability of the size of the dye particles, cells and pores of wood. 
As a result of the application of a rationally designed composition, the drying time of the coating is reduced to 21 minutes, which differs significantly from other alkyd resin-based coatings, the drying time of which is 180 minutes. This occurs because of the low content of varnish in the painting composition. A rational depth of penetration of the coloring composition into the wood (4.10 microns) was established. This depth of penetration was achieved due to the physicochemical properties of the solvent and low content of varnish in the painting composition.

Scientific novelty. The rational parameters of the coloring composition formulation based on alkyd resins for the formation of a paint and varnish coating on hardwood were determined; the new formulation provides improved performance indicators; the optimal technological parameters of applying the coloring composition and alkyd paint coatings on hardwood are determined.

Practical value. The use of the developed alkyd coloring composition provides high-quality coatings on hardwood, excluding the intermediate grinding operation, combining priming and painting at a sufficiently low cost. The use of an alkyd coloring composition reduces the surface roughness of painted wood by filling the cut cavities of cells and vessels with a primer-coating layer, creating a microfilm on the surface of the wood substrate, covering all structural irregularities. This composition is evenly distributed on the wood substrate, providing a uniform color, while maintaining the texture of wood.

Key words: painting composition, paint coating, varnish, white spirit, roughness, wood.

Стаття рекомендована до публікаиіі доктором технічних наук професором Луиьького НТУ Байдаковою Л.І. Дата надходження в редакиію 28.12.2018 p. 